\title{
CATALYST
}

feminism, theory, technoscience

\section{Defender la vida: Una entrevista con Raquel Gutiérrez Aguilar \\ [Defending Life: Interview with Raquel Gutiérrez Aguilar]}

Raquel Gutiérrez Aguilar

Benemérita Universidad Autónoma de Puebla

raquel.gutierrezaguilar@gmail.com

Firuzeh Shokooh Valle

Franklin \& Marshall College

firuzeh.shokoohvalle@fandm.edu

Vivette García Deister

Universidad Nacional Autónoma de México

vivettegarcia@ciencias.unam.mx

La primera vez que leí a Raquel Gutiérrez Aguilar sentí en sus palabras una emoción que desbordaba la página. No era sólo lo que decía, sino cómo lo decía. Había garra, urgencia; era visceral. Me removieron todo, transformaron cómo pensaba en mi investigación sobre activismo feminista, tecnología y desarrollo en Latinoamérica, y renovaron mi visión de lucha por un mundo mejor. Provocar esto con el pensamiento y la escritura no es poca cosa.

En estos días, mientras escribo un libro sobre la solidaridad y el placer como estrategias feministas de resistencia tecnopolítica, ando buscando a pensadoras latinoamericanas que alimenten mi mente y mi alma. Y se abrieron las compuertas cuando encontré a Raquel Gutiérrez Aguilar, entre tantas otras teóricas y activistas latinoamericanas y caribeñas que están pensando-y haciendo-nuestra región desde una profunda solidaridad feminista con lo 
humano y lo más-que-humano para re/construir este planeta que se destruye ante el avance inexorable del capitalismo. Su pensamiento y su praxis-sobre los bienes comunes, la autonomía y los movimientos comunitarios, los movimientos indígenas, las luchas feministas, la violencia contra las mujeres-se mueven por la siguiente pregunta fundamental: "¿cómo se garantizan las condiciones para la sostenibilidad de la vida?" (Gil 2017).

Raquel Gutiérrez Aguilar, de México, es una socióloga, filósofa y activista feminista. Es una "académica tardía", como me dijo durante nuestra entrevista, ya que estudió un bachillerato en Matemáticas en México en los primeros años de los 1980's y luego, durante más de dos décadas, fue militante de movimientos indígenas en Bolivia. Allí, militó en el Ejército Guerrillero Tupac Katari, y estuvo presa entre 1992-1997 por su militancia como guerrillera. Regresó a México en el 2001 y completó una maestría en Filosofía en la Universidad Nacional Autónoma de México y un doctorado en Sociología de la Benemérita Universidad Autónoma de Puebla, donde actualmente es investigadora-profesora. Algunas de sus obras principales son iA desordenar! Por una historia abierta de la lucha social (La Paz, 1995), Desandar el laberinto. Introspección en la feminidad contemporánea (La Paz, 1999), Los ritmos del Pachakuti. Movilización y levantamiento indígena-popular en Bolivia (2000-2005) (Buenos Aires, 2008, con una traducción publicada por Duke University Press en 2014), y Horizontes comunitario-populares: Producción de lo común más allá de las políticas estado-céntricas (Madrid, 2017), entre numerosos ensayos y antologías.

Leer a Raquel Gutiérrez Aguilar es un llamado a despertar tanto a las incontables catástrofes que nos acechan, como a las resistencias que nos nutren y a los sueños que perseguimos. Para comprender el feminicidio en México, es imprescindible leer su teorización de la violencia desde lo que llama la "amalgama triangular que teje el patriarcado, el capitalismo y el colonialismo, con cada vórtice apoyando los demás" en una combinación letal de "expropiación-explotación-dominación" (Gutiérrez Aguilar 2018b). Es necesario, urgente, leer su trabajo sobre la renovación coalicional de los movimientos feministas en Latinoamérica desde el 2017, y ese "horizonte del deseo" que "lo que busca es cambiar la vida toda", en "defensa de la vida" en un momento en el que "sabemos que necesitamos rechazar, impedir, inhibir, desactivar, confrontar, bloquear los múltiples dispositivos de despojo de nuestras creaciones más íntimas y decisivas, de todo aquello que nos permite cuidar y regenerar la vida en su conjunto, la humana y la no humana" (Gutiérrez Aguilar 2018a). También entender su visión de una "política en femenino", que lejos de reproducir binarios o esencializar el trabajo que históricamente han hecho las mujeres, se trata de un lenguaje "subversivo y desafiante" para "poder hablar de lo común, para nombrary visibilizar lo que desde otras miradas queda oculto, para relanzar la comprensión de la politicidad de procesos cotidianos y extraordinarios de defensa y cuidado de la vida, de las dificultades y fortalezas anidadas en ello (Gutiérrez Aguilar, Navarro Trujillo, \& 
Linsalata 2016". La "política en femenino" es una forma radical para repensary rehacer el mundo.

Cuando la revista Catalyst me pidió que entrevistara a Raquel Gutiérrez Aguilar a partir de un conversatorio en el que se discutió cómo la academia estadounidense sistemáticamente excluye a pensadores del sur, negros, indígenas, LGBTQI+ y nobinarias, y la lista continúa, lo primero que pensé fue: ¿lograré conseguirla? Pues logré dar con Raquel Gutiérrez Aguilar, quien, con cigarrillo en mano, me dio de su tiempo para conversar por zoom. ${ }^{1}$

Firuzeh Shokooh Valle (FSV): Me llamó mucho la atención la anécdota que cuentas en Desandar el laberinto sobre cuando escribiste el libro, y lo compartiste con tu entonces pareja y compañeros (todos hombres), y que les gustó, pero no se "conmovieron". ¿Cómo sus experiencias de vida y sus afectos han formado y guiado su pensamiento teórico y su activismo político?

Raquel Gutiérrez Aguilar (RGA): Es interesante que te hayas fijado en esa anécdota porque es algo que a mi me ha pasado reiteradas veces. Es decir, yo dividiría mi trabajo en dos clases de trabajo: el trabajo que hago sobre reflexiones de mis propias experiencias, y de conversaciones con otras mujeres y varones en distintos momentos de la vida que me permiten organizar mi propia experiencia. Y eso no es una cosa menor, nosotros le damos mucha importancia a "organizar la experiencia". ...Mis trabajos tenían que ver con esa serie de incomprensiones o de insatisfacciones, de resultados no esperados, es decir de cosas incomprensibles...

Me empecé a dar cuenta desde muy pronto, desde mi 30s, que había dos comprensiones de los libros, dependiendo del género, en un esquema muy binario que había en ese momento: que los varones entendían una cosa y las mujeres entendían otras, y me daban feedbacks absolutamente distintos. Eso me quedó siempre resonando. Soy una académica tardía, y cuando comencé a escribir artículos académicos, en un momento posterior que vuelvo a México, retomo la carrera académica, hago una Maestría en Lógica, siento totalmente la obturación parcial de esa capacidad expresiva que estoy buscando. Es decir, puedo decir cosas, pero me cuesta mucho trabajo decirlas. Siempre tengo que estar haciendo concesiones, siempre me siento atrapada en los formatos. Bueno, ahí estoy, y sigo viviendo esa contradicción. Entonces la navego, no renuncio a escribir, de hacer estos ejercicios de autoetnografía, de introspección, de objetivación de mi propia experiencia para lograr organizarla... Estoy escribiendo un libro, en serie, en el género epistolar, van a ser cuatro, y después quizás sea un libro. Y mientras tanto sigo trabajando en este otro lugar donde tienes que poner una introducción, unas palabras clave, un estado del arte... Cada vez me cuesta más trabajo hacerlo, cada vez me siento más encorsetada.

FSV: La academia es rígida, y exige unas fórmulas. 
RGA: Exacto, hay un cánon que permite y habilita unas voces, una clase de argumentos, y deslegitima, dificulta, y desprestigia otras. Ese es uno de los mil problemas que tiene. Por eso hablo de la palabra "encorsetar," en sentido del corsé que les ponían a las mujeres en el siglo 19, de atrapar las carnes y ajustarlas de alguna forma.

Esa palabra "conmover" la pienso mucho. ¿Qué queremos expresar cuando decimos conmover? Con-mover: movernos juntos. Es una constelación de palabras. Está relacionada con sintonizar, adquirir tono parecido, y resonar, es decir, vibrar al unísono, pensando en el sonido como emisión de onda. Esos dos elementos los pienso en la palabra "conmover", y que creo que por ahí viene lo que te llamó la atención. No conmueve porque no sintoniza, los otros no se ponen en el mismo tono de voz, porque están en otro, y están muy a gusto en otro. Y no re-suena, porque no pasa por el cuerpo, pasa solamente por la cabeza, no te dejas atrapar.

FSV: ¿Qué significa "defender la vida" como reclamo coalicional feminista ante el recrudecimiento de la violencia del orden colonial-capitalista y su expansiva crueldad contra las mujeres y los cuerpos feminizados? ¿Y cuáles son las implicaciones?

RGA: Quisiera expresar una cosa que es importante. No vengo de la tradición feminista. Mi procedencia de origen viene de la tradición de izquierda radical de América Latina. He tenido que revisar una gran cantidad de certezas y presupuestos marxistas. Y he encontrado en el camino una gran cantidad de mujeres como yo. Voy a tener 60 en dos años, soy el tipo de persona que no vivió el anterior despliegue de lucha feminista, pero me tocó el momento de la fuerza feminista de los 1970s ligada a las luchas antirracistas en Estados Unidos, etcétera, etcétera. Se estabilizaron agendas muy importantes y no cumplidas, pero muy insuficientes, a mi modo de ver: la agenda de equidad y la agenda de derechos sexuales y reproductivos.

De un momento de desborde muy grande en los 70s, en los 805 se habían estabilizado los "Women's Studies" en la academia anglosajona, y comenzado en algunas europeas, y se estaban abriendo nodos de investigación en las universidades en América Latina. No eran muy interesantes porque lo que estaban haciendo-además del trabajo de las historiadoras, que es lo que más me nutre-era un diálogo tenso para hacer arreglos de equidad y de consagración de derechos. No estoy diciendo que esas agendas no sean importantes, estoy diciendo que son insuficientes, y estoy diciendo que contienen el desborde. Siempre son una especie de cosita envenenada: por un lado, te empujan, y por otro lado te detienen. Son muy contradictorias. Y lo mismo con la agenda de derechos sexuales y reproductivos. De la agenda de autonomía radical del cuerpo 
de la lucha desde los 70s, a la agenda de derechos reproductivos, muy importante, pero limitativa. Para la mujer joven que yo era en los 80 no era atractivo. Un gran contingente de mujeres no se sintieron seducidas por el feminismo en los 8os', unas que sí, y hemos dado en nuestras luchas en estos cuerpos de mujeres en esta estructura amalgamada de expropiación-dominación. Y ese contingente es muy grande.

Los feminismos han vuelto a tener un momento de irrupción radical y masiva, como dice Vero Gago, ${ }^{2}$ en los últimos cinco años, desde marzo del 2017 que se visibilizó globalmente. [Anteriormente] en la práctica de las mujeres de izquierda, habíamos visto las reformas estructurales en América Latina, de privatización de los servicios públicos, de instalación de políticas de desposesión, de acaparamiento y monopolización de recursos básicos, de las tierras, de las aguas, de las semillas, de los bosques. Y allí se dieron, y yo pude participar, muchas luchas en defensa de esos bienes comunes. Participé fuertemente en la lucha contra la privatización del agua en Cochabamba [la Guerra del Agua], en una estructura organizativa que se llamó desde el 2000, "Coordinadora de Defensa del Agua y de la Vida". Entonces, "la vida" ya andaba dando vueltas. Siempre he pensado desde allí. Estas acciones de despojo, de expropiación, todo este desastre de las condiciones de sustento, la agresión sistemática, planteaba la importancia de desplazar hilos de los fundamentos de la reflexión. El problema era el modelo productivo que negaba todas las posibilidades de vida.

Y uno sigue aprendiendo, viviendo, y empiezas a entender las tramas comunitarias, tramas de interdependencia, que te hablan de lo humano y nohumano. Cuando defiendes el agua, el río, defiendes la posibilidad de pescar, entonces defiendes la trucha, las ranas, empiezas a pensar de una manera que ya no es ese pensamiento lineal, determinista, causal. Empiezas a pensar en bucles, de manera más compleja, en los ciclos metabólicos que se fracturan y se recomponen. Y ahí cada vez más surge esta cuestión de la defensa de la vida, la defensa de la vida digna, de la vida generosa. Se necesita el adjetivo. El argumento contrario a esto es que "el capitalismo también ofrece un modo de vida". Y es verdad. Pero a algunos les ofrece un modo de vida sostenido sobre la muerte y la radical destrucción de otros. Si tu no quieres eso, tienes que empezar a entender de modo más complejo.

Nosotras, el equipo con el que trabajo aquí en la Universidad de Puebla, tratamos de distinguir las formas de gestión de la interdependencia. La interdependencia es una condición de la vida, pero se gestiona de diferentes modos. Una manera de imponer unos términos de interdependencia fue el comercio triangular del siglo 17, esclavos negros, plantaciones, mercancías, algodón, etcétera. Lo que ves cuando los pueblos indígenas de acá ofrendan a la montaña, hacen ceremonias de petición de lluvia, es otra manera de gestionar la interdependencia. Eso está mal calificado como pensamiento mágico. El pensamiento realmente mágico es el del 
capital: que el dinero genera dinero, que el dinero es fértil. Es falso, eso es pensamiento mágico.... [Postpandemia] estamos viendo otra vez una reducción de todos los horizontes del deseo que se expresan cuando una coalición heterogénea se plantea defender la vida. Otra vez, es la vida individual, la de la persona vacunada, la de una producción científica privada... Y ahí estamos.

FSV: ¿Cuáles son las implicaciones de "defender la vida" ante el paradigma contemporáneo colonial-capitalista de la ciencia y la tecnología? Estoy pensando más en las tecnologías digitales, que es el área de mi trabajo investigativo.

RGA: Primero pienso, ¿dónde se abriría allí un terreno de lucha? Y desde allí eso me alumbra para ir entendiendo el otro conjunto de cosas. Por ejemplo, ¿cómo es posible que dentro de esto de las tecnologías digitales admitamos y no estemos haciendo un escándalo global gigante contra la obsolescencia programada? Para irnos al hardware, al objeto.... ¿Cómo no logramos ir planteando luchas más generales contra las barbaridades que lo único que garantizan es la ganancia empresarial? ¿Cómo tener montañas y montañas de objetos que dejan de servir? ¡Hazme el favor!

FSV: Es un proyecto en contra de la vida.

RGA: Eso es un proyecto en contra de la vida. Si tu te paras en defensa de la vida, y empiezas a ver el mundo desde ahí, se te aparecen otras aristas, de lo que no está bien, de lo que tenemos que pensar, deliberar, discutir. Nosotras hablamos mucho de que generalmente las luchas que se afianzan en contra de cosas tratan de producir vetos sociales. No es que tengamos pensado otro modo de vivir. Tenemos que comenzar poniendo límites a los aspectos más vitalmente destructivos, como eso.

En el sector educativo público, del que me honra formar parte, es una gran discusión: cómo para sostener la educación pública, tenemos que depender de una multiplicidad de redes privadas y de plataformas privadas. ¿Dónde está quedando lo público? ...Sentimos que siempre hay un terreno de disputa en cada objeto, en cada producción, cada cosa puede ser objeto de disputa. El asunto es que pareciera que no podemos darlo. Ha habido un avance radical en la privatización de estos medios tecnológicos, de conexión, de organización de la vida cotidiana y de organización de la vida laboral. Así lo vería, sin que sea el ámbito de mi "expertise"...

Nosotras [grupo de compañeras y colegas en la Universidad de Puebla] usamos la palabra "trama", en inglés weaving, para dar cuenta de la acción. Usamos otra palabra para el modo de cómo quedamos ensambladas a la máquina de la destrucción colonial-racista-acumuladora-financiera. Usamos las dos palabras: algo te ensambla, pero tu te tejes de algún modo. Nosotras dos ahora aun 
ensambladas a través de zoom y de una red de servicios privados, estamos tratando de tejer un vínculo.

FSV: Para terminar, y hablar un poco sobre lo que generó esta entrevista en primer lugar, ¿cómo responde a la exclusión sistemática de pensadoras de Latinoamérica en la academia anglosajona (particularmente en Estados Unidos)? ¿Y cuáles son las implicaciones de esta asimetría en la geopolítica del conocimiento?

RGA: Voy a decir una cosa que quisiera que no sonara arrogante. Claramente, siento esa asimetría de forma brutal. Es muy llamativo cómo empobrece tanto a la academia anglosajona. Estoy pensando mucho en los estudios postcoloniales de la India. Estudié eso hace muchos años, de la mano de Silvia Rivera Cusicanqui, ${ }^{3}$ y otras compañeras colegas. Los estudios postcoloniales, Spivak, etc., decían como el dominante si bien tiene mucha capacidad para destruir y para incidir, es mucho de lo que se pierde porque no conoce el otro idioma, y no le interesa. A veces con la academia anglosajona, siento eso. La anglosajona, directamente ignora, y ya está. No te ve, y listo. Empiezan a aparecer personas que recuperan elementos, que están buscando, como tú, digamos, lo que también ha de ser difícil de mantener. La academia europea no anglosajona, la francesa, la alemana, siempre nos está viendo y tratando de interpretarnos. Nos ve, pero nos reduce, nos ve, pero no nos toma en serio. Toma un pedacito y nos mete a su gran marco argumental. Pero hay un elemento que me gustaría poner en discusión: cómo las personas de los países ricos son a la larga más pobre que nosotras. Están más restringidas, más ensambladas a los circuitos de valorización que les limita sus posibilidades de libertad. ¿Cómo podríamos reconstruir relaciones de reconocimiento recíproco? Esa es una pregunta, y una pregunta que requiere de acciones prácticas...Cuando tu detectas un problema, si lo vuelves una pregunta de lucha, encuentras una mirada interesante para el hacer.

\section{Defending Life: Interview with Raquel Gutiérrez Aguilar Translated by Vivette García Deister}

The first time I read Raquel Gutiérrez Aguilar I felt in her words an emotion that overflowed the page. It was not only what she was saying, but how she was saying it. There was grit, urgency; it was visceral. Her words stirred up everything, they transformed how I thought about my research on feminist activism, technology and development in Latin America, and they renewed my view on the struggle for a better world. To have thought and writing provoke this is no minor achievement.

These days, as I write a book on solidarity and pleasure as feminist strategies of technopolitical resistance, I am seeking Latin American thinkers to feed my mind and my soul. The floodgates opened when I found Raquel Gutiérrez Aguilar 
among many Latin American theoreticians and activists who are thinking -and doing-our region based on a profound feminist solidarity with the human and more-than-human in order to re/construct this planet that succumbs under the inexorable advance of capitalism. Her thought and her praxis-on the commons, on autonomy and indigenous movements, on feminist struggles and violence against women- moves through the following fundamental question: How can conditions for the sustainability of life be guaranteed (Gil 2017)?

Originally from Mexico, Raquel Gutiérrez Aguilar is a sociologist, philosopher and feminist activist. She describes herself as a "late academic," given that she studied Mathematics in Mexico in the early 1980s and then militated in favor of Indigenous causes in Bolivia for over two decades. She joined the Ejército Guerrillero Tupac Katari and was imprisoned between 1992 and 1997 for her guerilla militancy. She returned to Mexico in 2001 and completed a master's degree in Philosophy at the Universidad Nacional Autónoma de México (UNAM), then she obtained a doctorate degree in sociology at the Benemérita Universidad Autónoma de Puebla (BUAP) where she is currently a researcher and professor. Some of her main works are ${ }_{i}$ A desordenar! Por una historia abierta de la lucha social (La Paz, 1995), Desandar el laberinto. Introspección en la feminidad contemporánea (La Paz, 1999), Los ritmos del Pachakuti. Movilización y levantamiento indígena-popular en Bolivia (2000-2005) (Buenos Aires, 2008, translated and published by Duke University Press in 2014), and Horizontes comunitario-populares: Producción de lo común más allá de las políticas estadocéntricas (Madrid, 2017), among numerous essays and anthologies.

Raquel Gutiérrez Aguilar's writing is a call to wake up to the countless catastrophes that trail us, but also to the resistances that nurture us and to the dreams that we pursue. Her theory of violence based on the "triangular amalgam that weaves patriarchy, capitalism and colonialism, with each vortex supporting the others" in a lethal combination of "expropriation-exploitation-domination" is indispensable for understanding femicide in Mexico (Gutiérrez Aguilar 2018 b). Of necessity and urgency is her work on the coalitional renewal of feminist movements in Latin America, and on the "horizon of desire" that "seeks to change the whole life" in "defense of life" at a time when "we know that we need to reject, impede, inhibit, deactivate, confront, block the multiple dispossession devices of our most intimate and decisive creations, of all that allows us to care for and regenerate life as a whole, both human and non-human" (Gutiérrez Aguilar 2018a). Also vital is her vision of a "politics of the feminine." Far from reproducing binaries or essentializing the work that women have historically done, it is a "subversive and defiant" language that "enables us to talk about what is common, to name and make visible what remains concealed to other gazes, to relaunch a comprehension of the 'politicity' of both quotidian and extraordinary processes of defense and care for life, and to acknowledge the difficulties and fortitudes nested 
in doing so" (Gutiérrez Aguilar, Navarro Trujillo, \& Linsalata 2016). The "politics of the feminine" is a radical way of thinking about and remaking the world.

When sparked by a discussion on how US academia systematically excludes other thinkers: from the south, Black, Indigenous, LGBTQI+, non-binary (the list continues), Catalyst asked me to interview Raquel Gutiérrez Aguilar. My first thought was whether I'd be able to get hold of her. I did. Cigarette in hand, Raquel Gutiérrez Aguilar made some time for a Zoom conversation. ${ }^{4}$

Firuzeh Shokooh Valle (FSV): Thinking about the anecdote that you tell in Desandar el laberinto about when you wrote the book and you shared it with your then partner and peers (all men), they liked it, but they were not moved (no se conmovieron). How have your life experiences and affects formed and guided your theoretical thought and your political activism?

Raquel Gutiérrez Aguilar (RGA): I find it interesting that you noticed that anecdote because that is something that has happened to me repeatedly. I would divide my work into two kinds: the work composed by reflections on my own experiences, and the work spurred by conversations with other women and men at different stages of my life that have allowed me to organize my own experience. And that is not a minor thing; we give great importance to organizing our experience...My works had to do with this series of misapprehensions or dissatisfactions, of unexpected results, that is, with what was incomprehensible.

Early on, when I was in my thirties, I began to notice that there were two understandings of my books that were gender-dependent in that very binary scheme that was prevalent at the time: men understood one thing and women understood another, and they each gave me completely different feedback. That stayed with me. I am a late academic. When I start writing academic papers-at a later stage, as I return to Mexico to do a master's in logic and revisit academia- I totally feel that partial closure of the expressive capacity that I am looking for. I am able to say things, but it is a struggle to do so. I keep having to make concessions, I feel constrained by the format. So, there I am, living that contradiction. I navigate it, I do not give up writing, I keep doing autoethnographic exercises, introspection, objectification of my own experience in order to organize it... I am writing a book of the epistolary genre; it's going to be four [epistles] and then maybe a book. And meanwhile I keep working from this other place where you must include an introduction, keywords, a state of the art...I becomes harder every time and I feel corseted.

FSV: Academia is rigid and it requires formulas.

RGA: Exactly, there is a canon that allows and enables some voices, a class of arguments, while it delegitimizes, hinders and discredits others. This is one of the 
many problems with academia. This is why I speak of "corseting" in allusion to the 19th-century corset what was put on women's bodies to trap the flesh and adjust it in a certain way.

I think a lot about the word conmover. What do we wish to express when we use it? Con-mover is to move (mover) together (con). It is a constellation of words. It is related to tuning in, to acquiring a similar pitch, to resonate, that is, to vibrate in unison if we think of sound as wave emission. These two elements inhabit the word conmover, and I think this is why it caught your attention. If something fails to conmover it is because it does not tune in, because people do not put themselves in the same tone of voice; they have another pitch and they are very comfortable where they are. It doesn't re/sound because it does not pass through the body, only through the head, and you don't get pulled in.

FSV: What does it mean to "defend life" as a feminist coalitional claim in the face of the resurgence of colonial-capitalist violence and its expansive cruelty against women and feminized bodies? And what does defending life imply?

RGA: I'd like to express something important. I do not come from the feminist tradition. I come from the radical left tradition of Latin America. I've had to revise a great deal of Marxist certainties and assumptions. And on the way I have found many women like myself. I'll turn 60 in two years. I am the kind of person who did not live the previous display of feminist struggle, but I did get to see the feminist force of the 1970 s linked to the anti-racist movement in the United States. Several important agendas were stabilized; they were unfulfilled, and they were insufficient in my view: the equity agenda and sexual and reproductive rights agenda.

From this overflow of the 70 s and 8os emerged women's studies in English speaking academia; women's studies also surfaced in some parts of Europe, and nodes of research appeared in Latin American Universities too. These were not particularly interesting because what was being done -in addition to the work of female historians, which is what has nurtured me the most-was a tense dialogue aimed at achieving equity arrangements and the consecration of rights. I am not implying that these agendas are unimportant; what I am saying is that they are insufficient, they contain the overspill. They have always been a poisoned little thing: on one hand they push you, on the other they cut you short. They are quite contradictory. It's the same with the sexual and reproductive rights agenda. From radical bodily autonomy in the 70 s to reproductive rights, the agendas are important but limiting. For the young woman I was in the 80 s this was unattractive. Many women were not seduced by the feminism of the 8os; some were, and we have all fought in women's bodies within this amalgamated structure of expropriation-domination. And that contingent has become very large. 
Over the last five years, since March 2017 when they earned global visibility, feminisms have once again irrupted radically and massively, as Vero Gago ${ }^{5}$ says. [Previously] in leftist women's practice we had seen structural reforms in Latin America, the privatization of public service, the establishment of a politics of dispossession, of hoarding and monopolization of basic resources: land, water, seeds, forests. Many struggles took place, and I participated in some of these fights in defense of those common goods. I strongly opposed the privatization of water in Cochabamba [the Water War] as part of an organization that in the year 2000 was named "Coordinadora de Defensa del Agua y de la Vida." Back then, "life" was already making its rounds. My thinking is rooted there. These actions of dispossession and expropriation, the disruption of livelihood conditions, the systematic aggression raised in me an awareness of the importance of displacing the foundations of reflection. The problem was the productive model that denied all the possibilities of life.

And by living one continues to learn, and you come to understand how communities are woven, the intertwined interdependence that speaks to the human and non-human. When you defend water, a river, you defend the possibility of fishing; then you defend the trout, the frogs, and you start to think in a way that no longer is linear or causally deterministic. You start to think in loops, in a more complex way, in the metabolic cycles that are fractured and reassembled. That is where the issue about defending life becomes recurrent, the defense of dignified life, generous life-adjectives required. The argument against this is that "capitalism also offers a way of life." And it is true. For some, capitalism offers a way of life that is sustained over the death and radical destruction of others. If you don't want that, then you have to begin to understand in a more complex manner.

We, the team that works here at the Universidad de Puebla, try to distinguish forms of interdependence management. Interdependence is a condition of life, but it is managed in different ways. In the 17th-century, triangular trade imposed the terms of interdependence: black slaves, plantations, manufactured goods, cotton, etc. When Indigenous people over here make an offering to the mountain, when they do rainmaking ceremonies, that is another way of managing interdependence. This is mischaracterized as magical thinking. Magical thinking is rather what capital does. The idea that money generates money, that money is fertile: that is false magical thinking...[Postpandemic] we are once again living a reduction of all horizons of desire that are expressed when a heterogeneous coalition considers defending life. Once again, it [the life usually preserved] is the individual life, the life of a vaccinated person, the life of a private scientific production. And here we are. 
FSV: What are the implications of "defending life" in light of the contemporary colonial-capitalist paradigm of science and technology? I am thinking particularly about digital technologies, which is the area of my research.

RGA: My first thought is: Where will a field of struggle open there? And this question sheds light on other sets of things. For example, why are we are welcoming these digital technologies without a giant global scandal against programmed obsolescence? How come we are not generally rising against the atrocities that only guarantee a business profit? Why do we accumulate heaps and mountains of objects that no longer serve us? Oh please!

FSV: It is a project against life.

RGA: That is a project against life. If you stand your ground in defense of life, and you begin to see the world from where you are standing, then other frames of reference emerge about what is right, what needs to be thought about, deliberated, discussed. We [fellow feminists and colleagues at the Universidad de Puebla] often point out that struggles that are defined in opposition to a certain issue try to produce social vetoes. We might not necessarily be thinking about fostering new forms of life. We must begin by setting limits on the most vitally destructive aspects, like that [the above-mentioned project against life].

In the area of public education, which I am honored to take part in, there is a key discussion. In order to sustain public education, we must depend on multiple private networks and private platforms. Where is the public in public education?...We feel as though every item, every production becomes an object of dispute. It seems as though we cannot put up a fight. There has been a radical advancement towards the privatization of technological media that connect and organize our daily lives and our working lives. Without this being my area of expertise, this is how I see things.

We [fellow feminists and colleagues at the Universidad de Puebla] use the word weaving (trama) to make sense of action. We use another word for the way in which we are assembled to the machine of colonial-racist-financial-hoarding destruction. In this way, using both words, we acknowledge that something assembles you, but you are also able to weave yourself in a certain way. You and I are currently assembled via Zoom and a private network that provides a service, but we are trying to weave a bond.

FSV: I'd like to finish by raising the issue that spawned this interview. What is your take on the systematic exclusion of Latin American thinkers by English-speaking academia (especially in the United States)? And what are the consequences of this asymmetry for the geopolitics of knowledge? 
RGA: I hope that what I am about to say does not sound arrogant. Clearly, I perceive a brutal asymmetry. What I find most striking is that this so impoverishes English-speaking academia. I am thinking about postcolonial studies in India. I studied that a long time ago, by the hand of Silvia Rivera Cusicanqui ${ }^{6}$ and other peers and colleagues. Postcolonial studies like Spivak's taught us that while the dominant [discourse] has a great capacity to destroy and influence, it also loses a lot because it is ignorant of another language or because it is not interested. Sometimes I feel this is what happens in English-speaking academia. It firmly ignores, period. It does not see you, and that's it. Every now and then there are people who take up elements [of Latin American investigations]. The nonEnglish-speaking academia in Europe (the French, the German) are constantly paying attention and trying to interpret us. They see us, but they do not take us seriously. They pick up a tiny piece and fit it within their grand argumentative framework. There is something here to be discussed: how, in the long run, rich countries are poorer than us. They are overly restrained, more assembled into the circuits of valorization that limit their possibilities of freedom. How might we go about reconstructing relations of reciprocal recognition? This is a question, one that requires practical action... When you detect a problem, if you turn it into a question about struggle, then you find an interesting outlook on action.

\section{Notes}

${ }^{1}$ La entrevista ha sido editada y condensada por razones de espacio y claridad.

${ }^{2}$ Verónica Gago es una intelectual y activista feminista de Argentina.

${ }^{3}$ Silvia Rivera Cusicanqui es una intelectual y activista de Bolivia.

${ }^{4}$ The interview has been edited for the purpose of clarity and abbreviated due to space restrictions.

${ }^{5}$ Verónica Gago is an Argentinian feminist intellectual and militant researcher.

${ }^{6}$ Silvia Rivera Cusicanqui is a Bolivian feminist and subaltern theorist. See https://en.wikipedia.org/wiki/Silvia Rivera Cusicanqui.

\section{References}

Gil, Sylvia L. 2017. "(Re)Producir la vida en común. La mirada de Raquel Gutiérrez Aguilar". Horizontes comunitarios, May 25, 2017.

https://horizontescomunitarios.wordpress.com/2017/05/25/reproducir-la-vida-encomun-la-mirada-de-raquel-gutierrez-aguilar-entrevista-por-silvia-l-gil/.

Gutiérrez Aguilar, Raquel, Mina Lorena Navarro Trujillo y Lucía Linsalata. 2016. "Repensar lo político, pensar en lo común. Claves para la discusión". In Modernidades alternativas, 317-477. México, D.F.: Facultad de Ciencias Políticas y Sociales UNAM, Ediciones del Lirio. 
Gutiérrez Aguilar, Raquel. 2018a. "Porque vivas nos queremos, juntas estamos trastocándolo todo: Notas para pensar, una vez más, los caminos de la transformación social". Revista THEOMAl 37: 41-55.

---. 2018b. "Women's Struggle against All Violence in Mexico: Gathering Fragments to Find Meaning." Translated by Liz Mason-Deese. South Atlantic Quarterly 117 (3): 670-81. https://doi.org/10.1215/00382876-6942245.

\section{Author Bios}

Raquel Gutiérrez Aguilar is a Mexican mathematician, philosopher, sociologist, and activist. She is professor of sociology and researcher at the Benemérita Universidad Autónoma de Puebla specialized in indigenous movements in Latin America, resistance, and social transformation.

Firuzeh Shokooh Valle is an Assistant Professor of Sociology at Franklin \& Marshall College, in Pennsylvania, United States. Her research explores feminist technopolitics of care in Latin America and other regions of the Global South.

Vivette García Deister is Professor of the Faculty of Sciences of the National Autonomous University of Mexico (UNAM). Her research currently focuses on the history of race science and the epistemologies of biomedical and forensic genetics in Mexico, as informed by ethnographic methods and the philosophy of science in practice. Orcid ID https://orcid.org/0000-0003-4207-5783. 